\title{
CRITICAL RECONSTRUCTIONS
}

The Relationship of Fiction and Life 
CONTRIBUTORS

John Bender

William M. Chace

George Dekker

Joseph Frank

Roger B. Henkle

Michael H. Levenson

Juliet McMaster

Thomas C. Moser

Robert M. Polhemus

John Henry Raleigh

Edward W. Said

Tzvetan Todorov 


\title{
CRITICAL \\ RECONSTRUCTIONS
}

\author{
The Relationship of \\ Fiction and Life
}

EDITED BY ROBERT M. POLHEMUS

AND ROGER B. HENKLE

STANFORD UNIVERSITY PRESS

Stanford, California 
In grateful memory of Roger B. Henkle

$$
\text { 1935-1991 }
$$

Stanford University Press, Stanford, California

(C) 1994 by the Board of Trustees of the Leland Stanford Junior University

Published with the assistance of the English Department, Stanford University

CIP data appear at the end of the book

Stanford University Press publications are distributed exclusively by Stanford University Press within the United States, Canada, and Mexico; they are distributed exclusively by Cambridge University Press throughout the rest of the world.

Original printing 1994

Last figure below indicates year of this printing:

$\begin{array}{llllllllll}04 & 03 & 02 & \text { OI } & 00 & 99 & 98 & 97 & 96 & 95\end{array}$ 
For Ian Watt,

with the contributors' gratitude, esteem, and affection 
